\title{
LINGUISTIC PERSONALITY OF METROPOLITAN ANTHONY OF SOUROZH (BLOOM)
}

\author{
Svitlana Shepitko \\ Mariupol State University, Mariupol, Ukraine \\ elti@mdu.in.ua \\ Mariia Smyrnova \\ Mariupol State University, Mariupol, Ukraine \\ m.smyrnova@mdu.in.ua
}

\begin{abstract}
The paper focuses on the essential problem of linguistic personality analysis. It aims to study language means representing linguistic personality of Metropolitan Antony of Sourozh (Bloom). The authors analyse the linguistic personality at three levels: semantic, linguo-cognitive and motivational. The linguistic personality is characterised through the prism of linguistic consciousness and speech behaviour, i.e. from the perspective of linguistic conceptology and the theory of discourse. The research results show that the linguistic personality's cornerstone is the concept "BELIEF" which is interpreted by various confessions differently. The metropolitan mainly uses questions which can occur in the quotes used during a sermon that transfers a listener to a format of a polilologue. The preacher most often addresses the tactics of conducting a dialogue and the tactics of "thought-reading". As a preacher, Metropolitan Anthony of Surozh is a representative of Orthodox Church as a social institute, whose picture of the world is also influenced by the national picture of the world which reflects religious, historical, cultural and political presuppositions of England as well as those of 20th century Western Europe. The authors state that the linguistic personality of a preacher experiences transformations under the pressure of secular society reflected at the verbal and semantic levels and, depending on a sermon recipient's type of personality - at the motivation level.
\end{abstract}

Keywords: religious discourse; English Orthodox sermon; linguistic personality.

\section{Introduction}

Linguistics starts to operate the 'linguistic personality' term when the scientific paradigm of humanitarian knowledge has changed, i.e. when the anthropocentric/functional paradigm has replaced the dominant structural approach. All the humanities are deeply interested in the "language and culture" field of study. This is a key idea which covers all the aspects of language study and at the same time eliminates the borders between humanitarian disciplines because we cannot imagine a person without his/her language. The 'linguistic personality' idea evolved in the 1980's, although the ties between human bearer and language functioning have always been evident for linguistics. The historical background of the aforementioned theory dates back to the 19th century. Generalised understanding of the 'linguistic personality' can be traced in the works by Wilhelm von Humboldt (Humboldt, 1998, p. 49), who considered language as "a reflector of the inner being of man" and as an exponent of the spirit and character of people as well as those of a nation. Being a representative of homo sapiens, who is able to combine a thought with a sound and to use the results of this activity of the spirit for communication, the linguistic personality is also a national personality, in other words, a native speaker is a generalised representative of his/her nation.

The term "linguistic personality" was for the first time introduced by Viktor Vinogradov in his work "On Fictional Prose" in 1930. He focuses on two approaches to the study of "author's image" and "artistic image as the linguistic personality" (Vinogradov, 1980, p. 259). But it was Yuri Karaulov who popularised this term. He considers the linguistic personality to be a person capable of creating and perceiving texts which differ in: 1) the degree of structural and linguistic complexity; 2) the depth and the accuracy of reality reflection; 3) the specific strategy (Karaulov, 2010, p. 84).

According to Maslova (2001), linguistic personality includes the following components: 1) the worldview component of education, i.e. the set of values or life goals; 2) the culturological component, i.e. the degree of cultural encompassing as an efficient means of increasing interest in language; 3 ) the personal component related to values, i.e. something individual and inner which everyone inherits (p. 119).

Karasik (2002) defines the linguistic personality as the generalised image of the media of cultural, linguistic, communicative and operational values as well as knowledge, attitudes and behavioural reactions (p. 46).

Thus, nowadays there are a lot of aspects of linguistic personality study which determine the status of his/her existence. To support this view, Nerosnak (1996) speaks about a multifaceted personality termed in other linguistic works as a complex, general or idiolectal personality. The analysis of such a multifaceted 
personality aims to reconstruct universal and distinctive features in lingual structures, vocabulary and the conceptual sphere (Nerosnak, 1996, p. 114). Snitko (1999) studies the linguistic personality from the viewpoint of limiting concepts of Western and Eastern civilizations (p. 13). Another type of the linguistic personality is a lexicographic one described by V. Karasik. It is understood as a carrier of axiological parameters of a certain ethnocultural community within the framework of binary oppositions of institutional discourse. In their recent work, Karasik and Gillespie (2014, p.24) state that discourse personality types can be based on psychological classifications of people which are very numerous and may be roughly subdivided as those based on temperament (natural qualities), directivity (demands and ideals) and abilities (intellectual, volitional and emotional peculiarities) which correlate with biological, social and spiritual features of a personality. Slavic philology outlines some other types of the linguistic personality, such as ethnosemantic (S. Vorkachev), elitist (A. Baranov), linguistic and speech personalities (Yu. Prochorov, L. Klobukova), emotional (V. Shachovskyi), psycholinguistic (I.A. Boduen de Kurtene, J. Rowe), linguo-didactic (V. Vynogradov), philosophical (J. Firth) ones, etc.

Having analysed all the definitions suggested, we came up with the following one. The linguistic personality is a possessor of cultural and linguistic competence that embraces all the information about language and culture on national, regional and world levels, and thus can be represented in several levels.

The linguistic personality of a religious leader is an object of theolinguistic studies. In the monograph by A. Sahalova (Salakhova, 2013), a profound analysis of confessional linguistic personality is provided on the basis of the German Protestant sermon. The theses of foreign researches are either the abstract analysis of the linguistic personality without any reference to its religious constituent or the parts of biblical studies and homiletics. Thus, it is obvious that such a research within the framework of linguistics is relevant enough.

The aim of the present research is to study verbalisation of different levels of the linguistic personality of Metropolitan Anthony of Sourozh (Bloom).

\section{Methods}

In the first place, we will consider the methods that are most commonly used in linguistic research of the linguistic personality, and then we will come up with the most preferable ones for the present study. Our analysis of literature shows that the research concerned with the linguistic personality traditionally involves a hypothetico-deductive model. Within this approach, certain assumptions and designed models are taken as the basis, and then it is checked if they can be experimentally verified. But a controversial approach (construcing a model of a speaker's linguistic personality while listening to his/her speech) is also used by the linguists Karaulov (2010), Kancher (2000). The approach is focused on the linguistic personality with its individual speech characteristics (Milovanova, 2012, p. 135).

To provide a complete and accurate description of the linguistic personality, reconstruction and analysis of its speech portrait are usually required. It is quite a popular method in linguistics which aims to outline specific features of the linguistic personality in the process of communication. However, no matter how much individual properties of speech are important, the researchers also consider the typical characteristics of certain social groups. This type of portraying seeks to identify the speakers' specific features on the basis of sociolinguistic manifestations (Milovanova, 2012, p. 136-137).

The differentiated speech portrait includes a hierarchically organised structure that comprises the following components: 1) socio-cultural parameters such as age, gender, place of birth, education, interests, hobbies; 2) common linguistic parameters, i.e. language phenomena (phonetic features, vocabulary, morphology, word formation); 3) differential linguistic parameters such as language phenomena in the field of phonetics, vocabulary, morphology, word-formation; 4) differentiating groups of dialects; 5) communicative parameters, i.e. features of communicative behaviour, a set of specific colloquial formulas, speech turns, lexical units, etc.

In the works studying the linguistic personality, two major methodological approaches are outlined. The first one is the reconstruction (i.e. a method of structural modelling, method of linguistic and rhetorical reconstruction, biographical method), and the second one is speech portraying (Zelyanskaya, 2012, p. 52). We also consider that it is possible to combine these approaches when the linguistic personality is described through its components' replication as well as observing reality facts.

Thus, the method of speech portraying presupposes observing an informant's speech behaviour and gradual description of his/her linguistic system levels. Thus, the selection of linguistic material is crucial for explication of a lingiustic personality, i.e. involvement of the fullest possible complex of texts generated by a speaker.

Synthesis of the methods, such as structural modelling (scrutiny of associative and verbal (vocabulary), cognitive (thesaurus) and pragmatic (pragmaticon) levels) and speech portraying (study of grammatical 
structure of utterances, stilystical means, including expressive means, means and manner of argumentation, etc.) makes it possible to provide the impartial, clear and thorough description of a lingiustic personality.

We use Yu. Karaulov's model for our further analysis (Karaulov, 2010, p. 84). It allows studying the linguistic personality at three levels:

1) the verbal and semantic level (lexicon of the personality and stereotypes, i.e. standard phrases and sentences as well as grammatical knowledge of the personality are in the focus of research. The relations of words are analysed in various grammatical, paradigmatic and syntactic links) (Karaulov, 2010, p. 101);

2) the linguo-cognitive level, representing thesaurus of the personality in which "the image of the world", or the system of knowledge of the world is imprinted. At this level, we reconstruct the linguistic model of the world on the basis of texts produced thereby, or the thesaurus of this person (Karaulov, 2010, p. 165).

3 ) the motivation level of the operational and communicative requirements reflecting a personality's pragmatic aims: the system of her/his purposes, motives, attitudes and intenttions (Karaulov, 2010, p. 211).

Hence, each level can be described as a combination of 1) components typical of this type of linguistic personality (if it is considered as a representative of its epoch, a certain social class, etc.) and 2) specific components typical of a certain native speaker only (Fesenko, 2013, p. 397).

Disclosure of the notion of a preacher's linguistic personality is impossible without considering the notion of a confessional (religious) personality (Lischer, 2011, p. 43). While studying the confessional linguistic personality on the basis of theological and philosophical works, Salakhova (2013) comes to the conclusion that the religious personality represents the personality whose cornerstone is the "BELIEF" concept understood by different confessions differently (p. 52). The researchers differentiate between Orthodox, Catholic, Protestant and other types of linguistic personalities which are in the Taxon-Type relations with the category of the confessional linguistic personality being hierarchically higher than the religious linguistic personality.

\section{Data}

In our study, we focus on the linguistic identity of the famous English Orthodox preacher metropolitan Anthony of Surozh (Blum) (1914-2003). Since 1958, Metropolitan Anthony had been ordained bishopry in London and several years later, he headed the Surozh diocese.

$\mathrm{He}$ is the author of numerous books and articles in different languages about spiritual life and Orthodox spirituality; moreover, he is a brilliant preacher. The material under research includes 100 samples of English sermons given by the metropolitan during his service in London from 1956 till 2000.

\section{Results and Discussion}

We aim to determine specific realisations of the metropolitan's linguistic personality at three levels. We will begin with the verbal and semantic levels.

Verbal and semantic levels. The metropolitan mainly forms questions which can occur in the quotes during preaching that transfers a listener to a format of a polilologue: Listen to what the Lord said to the Hebrews, from the lips of Isaiah the Prophet [Isaiah 58:3-8]: "... Wherefore have we fasted, say they, and Thou seest not? Wherefore have we afflicted our soul, and Thou takest no knowledge".

In many sermons, the syntactic structure begins with appellatives (from the direct address to the addressee, namely to the particular person, a group of persons or to an uncertain object) (Heather, 2010, p. 56). Such elements perform the contacting and emotive functions (Bugaeva, 2010, p. 89):

You know, faith according to the XI chapter to the Epistles to the Hebrews is certainty concerning things unseen.

In the metropolitan's sermons axiological elements are represented by adjectives of positive and negative assessment: loving, brave, great, common, magnificent, might, faithful, opposite, remarkable, deep, abiding, considerable, sweet and so forth. Metropolitan Anthony uses modal verbs and verb-forms capable of transferring the different level of confidence, for example: to know, to convince, to accept, to acknowledge, to recognise, to think, to believe and so on.

Volitional elements are represented by verbs which transfer desire: to wish, to want, would like:

But - he had a living soul; perhaps did he crave for more: who doesn't want to have a roof, who doesn't want to have the security of food? But he received what was given with gratitude.

In the implementation of the metropolitan's sermons, verificational elements (Lat. verificatia confirmation; Lat. verus - true, facio - I do) are embodied by means promoting the truth justification, for example:

But this is not the real and deeper meaning of it... What is what we really treasure?... 
The following textual means help to express ideas in a logical sequence (Smyrnova, 2017, p. 123): and, also, apart, from, besides, furthermore, in addition to, moreover, simultaneously, thus, to.

We have been given the knowledge of the existence of God, and indeed, a deeper, more intimate knowledge of God - all that is gift!

These means also include paraphrases and imposition: (as if, in the same way, in like manner, like, similarly):

...we are open to Him like the earth, the rich earth is open to the plough, to the sowing, to the seed, to the sunshine, to the rain, to everything in order to bring fruit.

Textual means also include causality (accordingly, as, because, consequently): Even those which frighten us are a gift because God says to us...), as well as contrast and comparison (alternatively, although, but if, however, nevertheless, otherwise, in spite of, on the other hand):

The Pharisee goes home, but he goes home less forgiven...

And, moreover, they include restriction (except, impossible, occasionally, only unless, if, only when):

...how can we learn anything about humility if that is the absolute condition to be not like the barren fig tree.

Expressivity in sermons of Metropolitan Anthony Surozhsky is verbalised by emotional and expressive means which include tropes that are not only the means of literary expression, but also the means of revealing sense (Zvezdin, 2012, p. 20), which is more important. A frequent use of a metaphor is possible to note ...the whole creation is waiting with longing for the revelation of the children of God.....and also repetition: He ... walks into a dye - He was dyed with the darkness of our sins.

The conceptual level. While analysing Metropolitan Anthony's toposphere of sermons at this level, it is possible to distinguish between several dominating toposes (Smyrnova, 2017, p. 111).

Topos "Salvation". Its realisation is caused by the need to tell believers about the main Christian commandmants, namely: why you need faith - for the rescue of soul and eternal life in the Kingdom of Heaven.

He claims from his, as God claims from us that we should be aware, and grow to the level of our human greatness: the children of the Living God called to be partakers of the divine nature, His sons and daughters in Christ and in the Spirit.

Topos "Sin". In the boundaries of that topos, the preacher reveals the notion of sin, its types, the reasons and consequences, tells about possible ways of its' avoidance, fight against it.

How simple and how restrained are the words in which the Gospel describes his cruel rejection of his father, and prepares his departure into the far, the strange country!

Topos "Repentance". The preacher's objectives and aims account for this topos' realisation. It is predominating because after the priest has convinced the person of the disastrous condition of his soul, he focuses on the need of self-understanding of sins, repentances, confessions and change in the way of thought and life (Gr. $\mu \varepsilon \tau$ óvota - "change of a thought", "reconsideration"):

It's one more step towards the day when in repentance we will come to make our confession, receive forgiveness. And if we were honest in our repentance, determined in our turning Godwards, we will be at home and ready to enter into Holy week together with Christ the Son, together with the Father Who gives His Son, together with the Mother of God Who accepts the death upon the cross of Her Son, that we may be saved. Amen.

Topos "Life-Death-Rebirth". Following the set direction, the preacher reveals the meaning of man's life, reminds of finitness of his earthy life and provides memories of the dead, their fate beyond the grave, focusing on the need of preparation for future eternal life "here and now":

That happens to us when someone who is infinitely dear dies. Then we discover that because this person has died everything which is shallow, trivial, small, too small to be as great as life and death, becomes irrelevant. We turn away from it, we become as great as our perception of life and death can make us.

Topos "God, Holy Virgin, Saints". Within this topos the priest unveils the essential aspects of God, tells about His life, His Mother, His Saints, their miracles and mental sets:

This feast of Nativity of the Mother of God is the time when we remember the birth of the One who for the sake of us all, for the whole human race, was able to show such faith, to surrender so absolutely to God, that He could become Man through Her, and bring us these manifold, unfathomable gifts.

The motivation level. We move to the last motivation level at which we'll examine Metropolitan Anthony of Surozh' pragmatic intentions. We will analyse some of the speech acts which are present in sermons of the metropolitan. Due to clarification of the information type given by the preacher, we can select such subtypes of representatives as:

1) Condemnation (the preacher is negative towards certain events, human actions and the way of thoughts that, according to church, is sinful or deceptive): 
He who does not love his brother is a liar when he says that he loves his God-these are the Apostle's words;

2) Forecasting (this subtype isn't typical of a traditional Orthodox sermon because Holy Fathers have commanded not to trust to oneself. Even if the person who leads a sacred life has abilities for future prediction, he hides them or tells by hints. For this reason, the preacher often warns people against forecasting and curiosity about their future, quoting the Sacred Writing that "... nobody knows this time either the God's Son or Angels, or people, only the Father" (Mk. 13, 32) and "many false prophets have appeared in the world" (John. 4, 1). Forecasting occurs in an Orthodox sermon only when the priest speaks about human sins - or qualities which will result in due time):

Tonight we will start on this journey; on the journey that leads us from our sinful condition, recognised, repentant unto a new time, unto the Resurrection of Christ, which is the beginning for us of our own eternal life. And we will then reach the point at which we must forget everyone and everything, and remember nothing, no one but the Lord Jesus Christ...;

3) Recognition (unlike other types of discourse, the Orthodox sermon is not characterised by the use of recognition as a representative generally because the preacher acts from WE - group; therefore recognition can be used in two forms - as a confession from all Orthodox Christians of the sinful nature before God or as a story from a historical or a fictional person and instructive recognition of the sins by them):

Now, no-one of us is put to the test in such a way. And yet, so often we are not prepared to accept God's word to us because we think that God could not speak that way.

Comissives are directed from a statement to reality, anticipate the corresponding intention, desire in the addresser and used by him for the purpose of obliging himself to do / not to do something. Traditional comissives (promises, oaths or guarantees) aren't used in sermons. Besides, the metropolitan has no powers to promise anything, except for the possibility of soul salvation in the church; he can guarantee that the truth is revealed in frameworks of Orthodox society):

He beats against the rocks like the sea, He breaks resistances... And may the Spirit of God ... come to us also - perhaps like a fire that sets us aglow and makes us like a Burning Bush...

In the sermons under research inhoatives are used by the metropolitan to establish the contact and for the flock to get ready to perceive the pastor's mental sets, to understand the main intention of his address (Lowry, 2014, p.27), for example:

We keep today the memory of Saint Mary of Egypt in the gradual progression from glory to glory which Lent is, and which must lead us step by step to facing the supreme glory of the Divine Love crucified, the sacrificial love of the Holy Trinity.

The process phase is shown in the logical and consecutive statement of thoughts, keeping listeners' attention, the emphasis being laid on the main substantial moments of a sermon:

So when we speak of faith and of believing we must learn... Now, we should be able to be to people around us an occasion for that kind of faith .... Let us read in the Gospel ... And we will discover that...

It is possible to distinguish between the following communicative tactics. The contacting discoursive strategy is implemented by means of rhetorical questions which the preacher answers:

Dare we say that we are so one with each other that nothing can break the bonds of solidarity and of love?

The tactic of "thought-reading" is a dominant one and it verbalises the contacting strategy. The preacher acts from "WE" - community, revealing those problems or secret thoughts, sins, hopes and sufferings the person hides in himself/herself.

Also, we will find within ourselves conflicting voices, saying, Don't! Don't make yourself ridiculous! Don't single yourself out by a search which is not necessary; you have got everything... Zacchaeus was rich, Zacchaeus was known as an honorable citizen - so are we!

Thus, the person feels a live part of a communicative process because whether he/she agrees with what has been told by the pastor or not, the parishioner gives a non-verbal answer.

\section{Conclusions}

Thus, having considered Metropolitan Anthony of Surozh (Blum)'s linguistic personality, we can make the following generalisations. The linguistic personality is the generalised image of the medium of cultural, linguistic and communicative, operational values, knowledge, presuppositions and behavioural reactions, the linguistic personality of the religious figure being the personality whose cornerstone is the concept "BELIEF" which is interpreted by various confessions differently.

The linguistic personality is traditionally analysed at three levels (verbal and semantic, linguo-cognitive, motivational). On the verbal and semantic level, the metropolitan asks questions in the form of quotes by 
which he transfers his parishioners to a polilologue format. Axiological elements of the sermon are represented by adjectives of positive and negative evaluation. Paraphrases and imposition are also used during preaching. At the conceptual level, we described Metropolitan Anthony's toposphere of sermons and such dominating toposes as "Salvation", "Sin", "Repentance", "Life-Death-Rebirth", and "God, Holy Virgin, Saints". At the motivation level such speech acts as condemnation, forecasting and recognition were analysed. The tactic of "thought-reading" is used by the metropolitan to show his understanding of parishioners' problems and desires.

As a preacher, Metropolitan Anthony of Surozh is a representative of Russian Orthodox Church as a social institute; his picture of the world is also determined by the national picture of the world which reflects religious, historical, cultural and political presuppositions of England and 20th century Western Europe. Thus, the linguistic personality of a preacher undergoes transformations under the pressure of secular society at the verbal and semantic level and, depending on a sermon recipient's type of personality - at the motivation level.

We see the prospects of the research in a comparative analysis of the linguistic personality's pragmatic intentions of alternate confessions preachers.

\section{References:}

Bugaeva, I. (2010). Jazik pravoslavnoy sfery: sovremennoye sostoyaniye, tendenzii rasvitiya [Language of Orthodox sphere: current status and development trends]. Moscow, Russia: Moscow State University.

Fesenko, O. (2013). Jazikovaya lichnost: $k$ voprosu ob interpritatsii termina [Language personality: the question of interpretation of the term]. Omsk, Russia: OEU.

Firth, J. (1950). Personality and language in society. London, UK : Oxford University Press.

Heather, N. (2010). Religious Language and Critical Discourse Analysis: Ideology and Identity in Christian Discourse Today. Pieterlen, Switzerland : Peter Lang Pub Inc.

Humboldt, W. (1998). Ueber die Verschiedenheit des menschlichen Sprachbaues und ihren Einfluss auf die geistige Entwicklung des Menschengeschlechts. Paderborn, Germany: Schöningh.

Kancher, M. (2000). O treh aspektah opisaniya yazikovoy lichnosti [Three aspects of language personality discription]. Yekaterinburg, Russia.

Karasik, V. (2002). Jazikovoy krug: lichnost, koncepti, diskurs: monografia [Language circle: personality, concepts, discourse]. Volgograd, Russia: Peremena.

Karasik, V., \& Gillespie, D. (2014). Discourse personality types. Tomsk, Russia.

Karaulov, Yu. (2010). Russkiy jazik i jazikovaya lichnost [Russian language and linguistic personality]. Moscow, Russia: Editorial URSS.

Lischer, R. (2011). A Theology of Preaching. Durham, UK: Labyrinth Press.

Lowry, E. (2014). Doing Time in the Pulpit: The Relationship Between Narrative and Preaching. Nashville, USA: Abingdon Press.

Maslova, V. (2001). Linguokultorologia [Linguoculturology]. Moscow, Russia: Academy.

Milovanova, M. (2012). Metody izucheniya yazikovoy lichnosti sovremennogo dialektonositelya [Methods of studying of modern dialect-bearer language personality]. Volgograd, Russia: VNU.

Neroznak, V. (1996). Lingvisticheskaya personoligia : $k$ opredeleniyu statusa diszipliny [Linguistic personality: on defining the status of a discipline]. Moscow, Russia.

Rowe J., Ha E. (2008). Archetype-driven character dialogue generation for interactive narrative. Berlin, Germany: Springer-Verlag Berlin Heidelberg.

Salakhova, A. (2013). Konfessionalnaya yazikovaya lichnost: kommunikativnye strategii i takniti [Confessional language personality: communicative strategies and tactics]. Tambov, Russia: Gramota.

Sermons of metropolitan Anthony of Sourozh (n.d.). Retrieved March 29, 2018 from http://masarchive.org/Sites/Site/Texts-ESermons.html

Snitko, T. (1999). Predelnye ponyatuya v zapadnoy i vostochnoy ligviculturah [Limit concepts in Western and Eastern cultures]. Pyatigorsk, Russia: PNU.

Smyrnova, M. (2017). Pravoslavna propovid u religiynomu dyskursi u 20 st.: ligvopragmatychniy aspect : monografia [Orthodox Sermon in Religious Discourse of the $20^{\text {th }}$ century: pragmatic aspect]. Mariupol, Ukraine: Mariupol State University.

Vinigradov, V. (1980). O jazike hudozhestvennoy prozi [Language of fiction prose]. Moscow, Russia: Nauka.

Zelyanskaya, N. (2012). Reconstruktsia "koordinat bytiya" yazikovoy lichosty politika kak metod linguopersonalisticheskogo opisaniya [Reconstruction of "being coordinates" of a politician's language personality as a method of linguopersonological description]. Chelyabinsk, Russia: ChNU.

Zvezdin, D. (2012). Pravoslavnaya propoved kak zanr zerkovno-religioznogo stilya sovremennogo russkogo literaturnogo yazika [Orthodox sermon as a genre of church and religious style in modern Russian literary language]. Chelyabinsk, Russia: Chelyabinsk State University. 